\title{
Technè
}

La science au service de l'histoire de l'art et de la préservation des biens culturels

43 | 2016

Une Europe de la recherche en sciences du patrimoine

\section{The CAMEO Project: aims and results}

CAMEO : objectifs et résultats

\section{Michele Derrick and Jean-Louis Boutaine}

\section{(2) OpenEdition \\ Journals}

\section{Electronic version}

URL: http://journals.openedition.org/techne/570

DOI: 10.4000/techne.570

ISSN: 2534-5168

\section{Publisher}

C2RMF

\section{Printed version}

Date of publication: 1 August 2016

Number of pages: $21-22$

ISBN: 978-2-7118-6338-9

ISSN: $1254-7867$

\section{Electronic reference}

Michele Derrick and Jean-Louis Boutaine, «The CAMEO Project: aims and results », Technè [Online] 43 | 2016, Online since 19 December 2019, connection on 25 July 2020. URL : http:// journals.openedition.org/techne/570; DOI : https://doi.org/10.4000/techne.570

\section{c) $($ ) $९$}

La revue Technè. La science au service de l'histoire de l'art et de la préservation des biens culturels est mise à disposition selon les termes de la Licence Creative Commons Attribution - Pas d'Utilisation Commerciale - Pas de Modification 4.0 International. 
Michele Derrick

Jean-Louis Boutaine
The CAMEO Project: aims and results

CAMEO : objectifs et résultats

Abstract. CAMEO (Conservation and Art Materials Encyclopedia Online at www.cameo.mfa.org), is a set of Internet databases that serve art-related professionals as well as the general public. In 2010, CAMEO established a collaborative agreement with CHARISMA scientists to enhance the content, breadth and transnational accessibility of the database. This process included adding about 10,000 non-English terms to the records for searching along with reviewing and updating record content. Success of this endeavor is illustrated through statistically examining the number and distribution of users from the beginning to end of the collaboration. By percentages, the total number of users increased by $80 \%$, and the relative percentage of the user pool outside the United States increased by $13 \%$.

The database is now based on a MediaWiki platform and resides on a cloud server, placing CAMEO in the unique position to offer homes to small collaborative databases that benefit the conservation and museum communities.

Keywords. Art materials database, conservation materials, analytical techniques.
Résumé. CAMEO (Conservation and Art Materials Encyclopedia Online; www.cameo.mfa.org) est une base de données en ligne destinée à la fois aux professionnels de l'art et au grand public. En 2010, CAMEO a entamé une collaboration avec des chercheurs du projet européen CHARISMA afin d'augmenter le contenu, le périmètre et l'accessibilité transnationale de la base de données. Ce partenariat a permis d'ajouter environ 10000 termes non anglais dans les outils de recherche, et de réviser et mettre à jour la documentation. L'analyse statistique du nombre et de la répartition des utilisateurs entre le début et la fin de la collaboration atteste le succès de cette initiative. Le nombre total a connu une hausse de $80 \%$, et de $18 \%$ hors États-Unis. La base de données CAMEO est maintenant disponible sur une plateforme MediaWiki et hébergée sur un cloud, ce qui la place dans la situation unique d'accueillir des petites bases de données collaboratives utiles aux restaurateurs et aux musées.

Mots-clés. Base de données des matériaux de l'art, matériaux de la restauration, techniques analytiques.

\section{Project Goals}

In 2006, the MFA formed a collaborative agreement with Eu-ARTECH (Access, Research and Technology for the conservation of European Cultural Heritage) to increase the international scope of CAMEO. In 2010, this partnership was redeveloped and extended with the CHARISMA (Cultural Heritage Advanced Research Infrastructures) European research project consortium that focuses on providing transnational access, cooperative research and networking applications in the field of cultural heritage conservation. These primary CHARISMA goals fit well with the concept of the CAMEO database, which tries to provide an easily accessed repository of technical information on art and conservation materials. To further develop CAMEO, the CHARISMA scientists contributed European language synonyms, images and information, as well as providing systematic review of the material records.

\section{Background}

CAMEO was developed by the Museum of Fine Arts, Boston, and placed on the internet in 1999. The primary CAMEO database combines technical, historical, chemical and visual information on historic and contemporary materials used in the production and preservation of artistic, architectural and archaeological artifacts. With more than 9,000 records, the knowledge base is broad because artifacts, sites and treatment methods can include any combination of materials that have been used in the history of mankind. Additionally, the amount of knowledge required for conservation is becoming even more important, due to factors such as increased availability of analytical techniques, better understanding of deterioration processes, wider selection of treatment materials, new emphasis placed on preventive conservation, and ever-growing concerns about health and safety.

Michele Derrick, Schorr Family Associate Research Scientist, Museum of Fine Arts, Boston (mderrick@mfa.org).Jean-Louis Boutaine, Forme Head of the Research Department of the Centre of Research \& Restoration of the Museum of France, C2RMF (jean-louis.boutaine@wanadoo.fr). 


\section{Accomplishments}

With this partnership, CHARISMA members have provided systematic review, correction and update of the material records, including the introduction of records concerning examination and analysis techniques developed in the frame of Eu-ARTECH and CHARISMA. Additionally, the working group contributed European language synonyms. This resulted in the addition of about 10,000 non-English synonyms to the database as an aid for searching records. Now users can enter either English or non-English terms into the MATERIAL search box. Both the primary name and the synonym list are searched simultaneously, allowing for records to be retrieved by their Dutch, French, German, Greek, Italian, Portuguese or Spanish names.

This collaboration helped expand the reach of the website into a broadly-used international resource. During the five year timeline of the CHARISMA working group project, CAMEO logged more than 1.5 million page hits in 219 countries. Further breakdown on the user distribution by Google Analytical statistics (Table 1), illustrates the impact that the CHARISMA work had on increasing the transnational use of CAMEO. The values for two one-month periods, January 2010 and January 2015, show the number and distribution of users of CAMEO at the beginning and end of the CHARISMA partnership. By percentages, the total number of users increased by $80 \%$, and the relative percentage of the user pool outside the U.S. increased by $13 \%$.

Table 1. Google Analytic Statistics for two separate one-month periods of online access to the CAMEO database. These months represent equivalent times at the beginning and end of the CHARISMA partnership with CAMEO illustrating the large increase in usage as well as the increased transnational use.

\begin{tabular}{|l|c|c|c|c|}
\hline Time Period & Sessions & Users & Countries & $\begin{array}{l}\text { \% users } \\
\text { outside the U.S. }\end{array}$ \\
\hline January 2010 & 5454 & 4111 & 97 & $48 \%$ \\
\hline January 2015 & 8910 & 7428 & 128 & $61 \%$ \\
\hline
\end{tabular}

\section{Further development}

In 2013, the CAMEO database was transferred from proprietary software and placed on a MediaWiki platform that resides on a cloud server. This transformation provided two significant changes for the active maintenance and growth of the database. First, it opened the database to the option of data entry by many volunteer editors. This update provided the flexibility to keep editorial restrictions, while also allowing easier, wide-spread contributions for revising and expanding the scope and content of our multi-functional information source. CAMEO currently has 52 editors in the U.S. and Europe (among them, 23 editors from 10 countries inside the CHARISMA consortium) and that number is continually growing. Secondly, the cloud server provides for virtually unlimited growth, which has placed CAMEO in the unique position to offer homes to small collaborative databases that benefit the conservation and museum communities.

\section{Summary}

CAMEO is a readily accessible resource that defines, characterizes and increases our understanding of materials found in historic and artistic works with a purpose of providing a time-saving resource for the conservation field where knowledge regarding material properties, reactivity and history can be crucial to success and safety. The partnership with CHARISMA has updated and expanded the database, especially through the contribution of about 10,000 non-English synonyms to the database as an aid for searching records. Success of this endeavor is illustrated through statistically examining the number and distribution of users from the beginning to the end of the collaboration. By percentages, the total number of users increased by $80 \%$, and the relative percentage of the user pool outside the U.S. increased by $13 \%$. The MFA greatly appreciates the CHARISMA partnership with the CAMEO group and hopes that the collaboration with the European Union museum scientists can continue. 